inOedia $\quad \begin{aligned} & \text { InMedia } \\ & \text { The French Journal of Media Studies }\end{aligned}$

2| 2012

Performing/Representing Male Bonds

\title{
The Reluctant Patriarch: The Emergence of Lads and Lad Mags in the 1990s
}

Nick Growse

\section{(2) OpenEdition \\ 1 Journals}

Electronic version

URL: http://journals.openedition.org/inmedia/428

DOI: $10.4000 /$ inmedia.428

ISSN: 2259-4728

Publisher

Center for Research on the English-Speaking World (CREW)

Electronic reference

Nick Growse, "The Reluctant Patriarch: The Emergence of Lads and Lad Mags in the 1990s », InMedia [Online], 2 | 2012, Online since 05 December 2012, connection on 08 September 2020. URL : http:// journals.openedition.org/inmedia/428; DOI : https://doi.org/10.4000/inmedia.428

This text was automatically generated on 8 September 2020

(C) InMedia 


\title{
The Reluctant Patriarch: The Emergence of Lads and Lad Mags in the 1990s
}

\author{
Nick Growse
}

1 In contemporary British culture, there seems to be a demand for representations of weak men. As John Beynon observes in Masculinities and Culture, published in 2001 "Popular films and television shows, videos, advertisements and magazines are full of images and narratives of weak men unable to cope with the demands made on them. [...] These representations of men are very different from the former male paradigms of husband and breadwinner". ${ }^{1}$ This representation is particularly associated with humour. The 'hopeless man' has been an essential characteristic of British television comedy since Dad's Army, ${ }^{2}$ developed subsequently in Some Mothers Do Have em, ${ }^{3}$ Whatever Happened to the Likely Lads, ${ }^{4}$ Fawlty Towers ${ }^{5}$ and Only Fools and Horses ${ }^{6}$ and the award-winning Men Behaving Badly. ${ }^{7}$ In all these cases it is the essential incompetence of the masculine protagonist that produces the comedy. In the most recent of these, Men Behaving Badly, the two protagonists Gary and Tony, although presented sympathetically, are not only incompetent and absurd, but also selfish, inconsiderate, cowardly, vainglorious, emotionally undeveloped and unprincipled. The inclusion of feminine partners, as in Whatever Happened to the Likely Lads, Fawlty Towers, the third series of Only Fools and Horses and Men Behaving Badly serves to highlight the peculiarly masculine nature of the incompetence. The male protagonist is afraid of his partner's judgement; he seeks to hide evidence of his weakness or incompetence, by dissimulation, bluster and lying, until finally all his absurd efforts are laid bare. The feminine partner, on the other hand, is continually disappointed or exasperated by her 'man' but forgives him in the end, as she would a child, because she loves him. This attitude is epitomised by a comment in the six part series Micawber ${ }^{8}$, based on the character from Charles Dickens; at the end of the third episode, Mrs Micawber, having saved her pompous and vain husband from a 'situation', says to him indulgently: "Like all men you are foolish and weak". The Mrs Micawber of Charles Dickens was unfailingly courteous towards her husband and did not express such thoughts. We may 
take her harsh view of men to be more a reflection of contemporary attitudes not those of Dickens.

More recently, it has been suggested that this negative perception of men has become a dominant theme in the media. An article about advertising in The Observer in 2002 claimed that "men are fed up being depicted [...] as incompetent, brow-beaten slobs, who cannot express themselves, hold down a job, clean the house or keep a girlfriend". ${ }^{9}$ The television critic Chris Dunkley complains that men on television "are seen as inept nerds, useless except for providing women with canned beer and not even the occasional orgasm, which is quite beyond them". ${ }^{10}$ This perception is not restricted to television. A book review in the Independent Magazine complains about the recurrent theme of "hopeless men" in the contemporary genre of novel called lad literature or ladlit, inaugurated by Nick Hornby ${ }^{11}$ and Tony Parsons ${ }^{12}$ and the reviewer Brandon Robshaw, notes that "the female lead mainly functions as a personified super-ego, frowning on the lads' wayward behaviour". ${ }^{13}$ Although a female equivalent of the lad, the 'ladette', has been documented, it receives little representation in drama and women are more generally represented as victims of laddish excess or inadequacy. An American writer, Gary Taylor, having spent a week in London theatres in 2003 and describing the experience in The Guardian, concludes that in Britain "the women never have orgasms, the men are all assholes". ${ }^{14}$

3 Popular science writing seems to endorse this view of men. In The Essential Difference, Simon Baron-Cohen, director of the Cambridge Autism Research Centre, argues that if autism is considered as a sliding scale of emotional response on which everyone tends to cluster round a mid-point, men tend to be above the mid-point, generally displaying more signs of autistic behaviour than women. Neo-Darwinian thinking, ${ }^{15}$ perhaps best exemplified in The Selfish Gene by Richard Dawkins, the Oxford professor of zoology, sees the male sex throughout the animal kingdom as a sexual parasite, seeking to minimize its share of the work of reproduction, although Dawkins himself does not directly relate his conclusions to humanity. The geneticist Steve Jones's Y: The Descent of Man (2002) about which the Australian feminist writer Germaine Greer, known for her outspoken views, comments on the back cover, "Steve Jones is much harder on men than I am". There is evidence that this representation of men has affected the way people think about gender. Following the recent statistical successes by girls and women at school and University, newspapers have often chosen to focus on masculine failure, with headlines such as: "So, it's a woman's world. The future looks to be female as women continue to perform better than men at school, in university and in the workplace." ${ }^{16}$ A sociological study by a team from the University of Kent shows that school children as young as four, boys as well as girls, believe that girls are more successful and more focused than boys. ${ }^{17}$

4 In theoretical terms, this representation of men might well seem anomalous. In sociological analysis, gender has most usually been seen as an ideology that is to the advantage of men and to the detriment of women. For example, the American sociologist R. Connell wrote that the "collective interest of heterosexual men" is "broadly to maintain the existing system" ${ }^{18}$ Arthur Brittan calls this ideology "masculinism", argues that social discourse is masculine ${ }^{19}$ and that, however varied, masculinities are to do with the exercise of power. ${ }^{20}$ Hegemonic masculine power or "masculinism" is often supposed to operate invisibly and pervasively, as Pierre Bourdieu argues in La Domination masculine: 
The strength of masculine order is apparent in the fact that it does not require justification: the androcentric worldview has successfully passed itself off as neutral and has no need to legitimate itself overtly through discourse. (My translation $)^{21}$

5 By appropriating language itself, masculinity can define its own characteristics and become synonymous with strength, prestige and power. In Masculin/Féminin: La pensée de la différence, the French anthropologist Françoise Héritier traces the polarisation of gender characteristics through African and Far Eastern ethnic cultures and languages, concluding that the masculine principle is systematically associated with warmth, action and completeness, whereas the feminine is left with cold, passiveness and incompleteness. ${ }^{22}$ She goes so far as to suggest that this linguistic polarisation in favour of men may be considered as a fourth pillar to be added to the three identified by Claude Lévi-Strauss as common denominators of all human society. ${ }^{23}$ The greater value conferred on masculinity serves to underpin and justify the structural inequality between the sexes.

The English language, though not included in her study, would tend to support her thesis. Although Doctor Johnson's first English dictionary, published in 1786, does not even mention masculinity, the adjective "masculine" includes the definition "virile, not soft, not effeminate", while "manliness" includes "dignity" and "manly" includes the synonyms "brave, stout, undaunted, undismayed". "Feminine", on the other hand, after "soft, tender, delicate", is defined as "effeminate, emasculated, wanting". The notion of "wanting" or "lacking" is illustrated by a quotation from Milton's Paradise Lost in which the feminine sex is described as "this fair defect of nature". ${ }^{24}$ Although recent editions of the concise Oxford dictionary (revised $11^{\text {th }}$ edition, 2008) avoids these synonyms, a glance at Roget's Thesaurus ( $6^{\text {th }}$ edition, 2002) shows that they are still in currency.

7 If social discourse is masculine, if men have universally appropriated language and definitions to their advantage, then how do we explain the representation of the weak man? Chris Dunkley, the television critic quoted above by the Observer, thinks that feminism, or else an increasing feminization of society, is at the root of this negative masculine image. This view has a certain non-academic support. In France, writers and journalists like Eric Zemmour and Alain Soral, have written polemical books about the feminization of society to the detriment of men. Robert Bly, the American poet and writer, founder of the "mytho-poetic" men's movement ${ }^{25}$, writes in the introduction to his best-selling book about men Iron John: A Book About Men that he began to notice increasing numbers of "soft" and "unhappy" men in the 1970s, often accompanied by radiantly strong women ${ }^{26}$ with the obvious implication that men are being dominated by their women. A common theme in mytho-poetic and neo-Jungian writing, and the central image in Bly's Iron John, is that the key to a man's masculinity has been taken by a woman in his life, whether mother, wife or girlfriend. As another neo-Jungian writer Sam Keene, author of Fire in the Belly, asserts in a chapter entitled "It's a woman's world", and a section entitled "Man's Unconscious Bondage to WOMAN", "we never acknowledge the primal power WOMAN wields over us. The average man spends a lifetime denying, defending against, trying to control, and reacting to the power of WOMAN" (his capitals). ${ }^{27} \mathrm{~A}$ book published in 2002 by two Canadian academics from the field of Religious Studies, entitled Spreading Misandry: The Teaching of Contempt for Men in Popular Culture, attributes popular contempt for men specifically to the influence of the feminist movement. ${ }^{28}$ 
8 The problem with this argument is that in every case cited above, in which the male is represented as weak, whether a television comedy, West End play, novel or other book, the author is a man (and in the case of the television comedies, the producers are also men). It would also seem that amongst writers on the subject of gender, it is above all men who emphasize masculine weakness, fragility or vulnerability; Andrew Tolson talks of "the fragile masculine identity", ${ }^{29}$ Arthur Brittan of "the extreme vulnerability of the masculine identity", ${ }^{30}$ Pierre Bourdieu of "the immense vulnerability" of "the impossible ideal of virility" (my translation), John Beynon of "conventional masculinity" being "more often than not a false skin hiding deep insecurities", ${ }^{31}$ Mairtin Mac an Ghaill of heterosexual masculinity as "a highly fractured and fragile construction". ${ }^{32}$ Steve Jones, the geneticist, talking of the biological foundations of maleness, says that "masculinity emerges as a fragile and uncertain thing which is often forced to reinvent itself." " Even Eric Zemmour, an apologist for unreconstructed and atavistic masculinity, asks: "What is more fragile and mysterious than masculine desire?" ${ }^{4}$ The militant feminist writer Andrea Dworkin, writing in the 1970s, complains with apparent exasperation that "men dare to claim not only that they are fragile but that the power of women over them is immense and real". ${ }^{35}$

Perhaps more significantly, the men's magazine market that took shape in Britain in the $1990 \mathrm{~s}^{36}$ seems to show that the representation of the weak man is not only produced by men but also appeals specifically to a masculine audience. As Frank Mort has shown in Cultures of Consumption, there was, over the course of the 1980s, a sustained attempt by magazine publishers and advertisers to find a formula for a successful, generalist men's magazine which would serve as a marketing platform to a unified masculine market. ${ }^{37}$ As Mort shows, most of the magazines, even those with big promotion budgets like Cosmo Man or The Hit, closed after a few issues or else, like The Face or Arena, settled into a relatively small niche market of men's fashion. Many publishers believed that men did not wish to identify with their gender ${ }^{38}$ Cruelly for Mort, his study just missed the spectacular success in 1994 of two magazines that finally seemed to have found a successful formula: Loaded from the publishing house IPC, and FHM from EMAP Metro. Loaded, the first, passed 100,000 copies sold on its ninth issue. ${ }^{39}$ The real, longer-term success, however, belonged to its rival, FHM, whose monthly sales went from approximately 60,000 in 1994 when EMAP took the title over, to over 750,000 in $1998,{ }^{40}$ inspiring a number of imitators and creating a vast new publishing market. The editorial of the first issue of Loaded in May 1994, captures the tone of both magazines:

Loaded is a new magazine dedicated to life, liberty and the pursuit of sex, drink, football and less serious matters. [...] Loaded is for the man who believes he can do anything, if only he wasn't hung over. ${ }^{41}$

At face value, both Loaded and FHM were constructed in a spirit of popular, masculine, working-class hedonism, reminiscent of that of Paul Willis's "lads" in Learning to Labour $^{42}$, and in contradistinction to middle-class, politically correct values of selfcontrol and moderation, although the target of both magazines included middle-class and successful professional young men. As Tim Southwell, one of the founding editors of Loaded, wrote later in his history of the magazine: "Loaded had clocked onto the fact that there was another kind of Britain than the Beefeater, fucking around in Florence, that kind of high-brow Britain". ${ }^{43}$ Both magazines quickly became known as 'lad mags' and became emblematic of a new atavistic and 'laddish' masculine culture, appealing to all social classes, based on male camaraderie, drinking and the pursuit of pleasure. 
Carolyn Jackson, in her book on masculine failure at school, Lads and Ladettes in School: Gender and a Fear of Failure, claims that laddism is a "hegemonic masculinity". ${ }^{44}$

Most studies of lad mags, such as Making Sense of Men's Magazines, ${ }^{45}$ have tended to emphasize the riotous and hedonistic side of laddism. However, in Loaded and FHM, as well as their weekly successors Nuts and Zoo the representation of the weak man plays an important part. According to an Observer Review report in 2005, marvelling at the rise and continued success of these magazines "their message was: 'Don't take us seriously. We're blokes and we're useless'." ${ }^{46}$ Prior to the launch of FHM in France in 2001, focus groups of French men seem to have spotted and rejected this message, which suggests that it appeals to a specifically English or English-speaking culture. Amongst the key recommendations of the launch report presented to the management board of EMAP France, we find the following: "L'autodérision est à consommer avec modération"47 ("self-mockery is to be taken in small doses"). This is firstly apparent in the magazine's representation of the male body. Unlike Men's Health, which claims to be the best-selling men's magazine in Germany (and which generally shows a worked-out, semi-naked male body on the front cover), FHM has no interest in male beauty. The front cover is reserved for a beautiful female body, and any men pictured inside the magazine tend to be homely at best, often with a noticeable beer gut, in the image of the magazine's star reporter in the 1990s, Grub Smith. It is the same with masculine character. There are various columns and spaces - "True Stories", "Vital Signs", "FHM Confession" - to which readers are invited to write in recounting their most shameful or demeaning moments. These may concern social or sexual humiliation, such as one man whose plan to spice up his sex life by dressing up as a baby for his girlfriend, ended so badly that he not only lost his girlfriend but he also had to leave the village where they lived. ${ }^{48}$ More often, however, the confessions deal with more banal and yet more revealing events. For example, a confession sent to "FHM's incessant Laundromat of honesty" in November $2000^{49}$, is about a man who wanted to get rid of two goldfish as he was going to move to a new flat. It turns out that he had originally bought the goldfish to show his girlfriend that he had a 'nurturing' side to his character. Wishing to hide the deed from her, he tries to stage a fatal accident, but finds that he is too squeamish to kill an animal 'properly' (as his father had taught him). Eventually, afraid that his girlfriend will discover the truth, he flushes the fish down the toilet. He turns out to be guilty of dishonesty, cowardice, hypocrisy, unfeeling cruelty, incompetence and spinelessness, but the magazine offers no judgement. The girlfriend in both stories appears, to borrow the phrase of the Independent book critic Brandon Robshaw quoted above, as "a personified superego".

In interviews with celebrities and stars there is a similar interest in uncovering unpalatable truths and the 'real man' behind the mask, which is totally unlike the soapily avuncular tone that FHM adopts with the beautiful actresses or female pop stars who model for the magazine. When it interviews sports stars, it would like to know about deliberate violence and cheating ${ }^{50}$ or secret homosexual longings in the baths after the match. ${ }^{51}$ When talking to celebrities, it wants to know whether they take advantage of "dangerously young" female fans..$^{52}$ More generally, the magazine likes to ask about attitudes to masturbation and farting..$^{53}$ It can be deliberately provocative in order to unsettle the interviewee, often playing ironically with the tropes of traditional masculinity; for example in an interview with the singer Jose Washbourn, the interviewer starts by asking: "Have you always had that incredibly bouffant hair style - 
as in big, curly and more than a bit girlie?" ${ }^{54}$ If an interviewee becomes angry with their needling style, the interviewer might ask, as he did to Corey, the lead singer of the American band Slipknot: "Do you want a hug?" 55 There is a long-standing column called "The Bloke Test" in which two stars are pitted together, answering the same questions and marked according to FHM's value system "to decide who is least like a big girl". ${ }^{56} \mathrm{~A}$ man who is not like a "big girl", however, is apparently one who can confess to anything without shame, who is without pretension, who is at ease with his weakness. A classic example of this is the closing exchange of an interview with the singer of American punk band Blink 182, Mark Hoppus in December 2000. FHM says: "Clearly you are a man of little shame. Fancy a career in porn if the band goes belly up?" Hoppus replies calmly that his penis is too small and he lacks sexual endurance. In FHM's world, it is the perfect reply. ${ }^{57}$

In other words, the representation of the weak man, within Britain at least, would seem to be generated by men for consumption by men. If we assume that there is an interactive relationship between supply and demand, then it would seem that British men want to consume (and perhaps even identify with) these images of weak masculinity, which are so far removed from the patriarchal ideal. What is more, the magazines belong, as we have seen, to a wider cultural phenomenon called "laddism" or "new laddism". ${ }^{58}$ According to The Observer, laddism is "the defining male attitude of the decade".$^{59}$ This would put the image of the weak man at the heart of a very widespread complex of contemporary heterosexual British masculinities.

From this brief overview of the magazine it might appear that there is at the heart of British masculinities in the 1990s and 2000s a popular critique and a deconstruction of masculine mythology, created by men for men. In other words, the representation of the 'hopeless bloke' in popular culture, which is experienced on an immediate level as funny, could reflect a deeper desire amongst men to unmask, to reveal the truth and to 'debunk' the myths of masculinity. However, this hypothesis leads to the question posed in the opening paragraph: why would men want to challenge a masculine ideology and representation which has traditionally been to their advantage? Is it, as Rowena Chapman might suggest, ${ }^{60}$ another protean mutation of the dominant masculine discourse, endlessly adapting to new circumstances and social environments in order to hold on to power, assimilating new critiques into its own structure, taking the weapons of its enemies and making them its own? The problem here is that if this is a cunning plan, it is perhaps too cunning for the ordinary men who buy the magazine. And it is not clear how a discourse of masculine weakness and irresponsibility can lead to social power and control.

Or could this be a genuine male liberation movement, utterly unlike the one inspired by second wave feminism in the 1970s, but similarly motivated by a desire to shed the mask, to stop the performance, to discover a real, authentic self? The problem here is that "laddism", or "new laddism", is almost pure performance; on one level public displays of masculine drunkenness and excess, but also literally a popular performance of masculinity on television shows such as Men Behaving Badly, and finally, of course, a commercial discourse dreamt up by the advertising agencies and publishers. ${ }^{61}$ As the term "new laddism" suggests, the behaviour it represents is an imitation, a copy, inspired by the working class lads that the cultural theorist Paul Willis describes in Learning to Labour. However genuine the desire for authenticity, we end up with yet another performance. 
16 I would like to examine another possibility suggested to me during the course of my own research into lad culture. I used my study of FHM to construct a survey of the magazine's target group - which I defined as British men who had left school, aged between 17 and 35, and were not married or with children. My intention was to examine to what extent the interests and concerns of FHM, which I had identified through a contents analysis of twelve issues over a three-year period, corresponded to those of its supposed readership. There was no formal questionnaire, but a series of subjects - manhood, couple relationships, violence, friendship, family, work, marriage, happiness - on which I sought to elicit the interviewee's attitudes. The interviewees were under the impression that I was simply recording their life-history. Instead of asking leading questions I tried to follow the interviewee's own discourse by picking up or 'echoing' interrogatively his own words. I recruited my first interviewees through informal contacts from different geographical environments and socio-economic backgrounds and then used the 'snowball' technique of gaining access to the initial contact's entourage. For reasons of convenience I concentrated my interviews in the South East of England, going no further north than Birmingham and no further west than Bath. In the end I managed to complete 60 interviews lasting between 90 minutes and 3 hours. ${ }^{62}$ Perhaps unsurprisingly, compared to the 2001 Census, ${ }^{63}$ the sample was representative in terms of family background, ethnicity, home environment (big city, town or village) and educational background.

During the course of these interviews, I was struck by two particular common threads that emerged in the discourse of the interviewees. The first concerns the notion of manhood. ${ }^{64}$ While 9 had no notion of what manhood might mean or else rejected the concept as outdated, a majority of the rest thought that being a man meant responsibility. 22 spontaneously used the word, while 9 others talked about being financially responsible for a family as a necessary criterion for manhood. Implicit in the idea of responsibility seems to be a notion of getting a good job, buying a house and entering into a steady relationship, as emerges in this exchange with Brian, a 28-year Londoner who claimed to have been amongst the first to buy Loaded, a first adopter of laddism so to speak, and who was currently working as a musician in a band:

N.G. Do you consider yourself to be a man?

B. Not necessarily no, because a lot of people's perception of what being a man is, there's a certain amount of responsibility. I think it comes with being a man and I wouldn't say that I am that responsible.

N.G. Responsibility?

B. Yeah.

N.G. What sort of responsibility?

B. Like having a good job, house, mortgage, car and family, kids. ${ }^{65}$

Brian's definition of being a man is very reminiscent of the "masculine role", identified in the 1940s and 1950s by American functionalists such as Talcott Parsons ${ }^{66}$ and Mirra Komarovsky ${ }^{67}$ In this view, given that we have no natural instincts of reproduction, society inculcates certain behaviour patterns to regulate the work that reproduction entails - the "feminine role" of the homemaker and the "masculine role" of the "provider". ${ }^{68}$ Second wave feminists deconstructed sex roles to show that they were a structural element in gender inequality. For example, the American feminist writer Gloria Steinem, in an essay entitled "The Masculine Mystique", argues that the masculine role implies "masculine superiority" while the "feminine role" implies second-class status. ${ }^{69}$ We can go further and see the hand of Calvinist patriarchal 
theology which places men in the bounded context of work and family, as Max Weber describes in The Protestant Ethic and the Spirit of Capitalism. ${ }^{70}$ In the contemporary masculine role as in the Puritan model, certain key concepts are inextricably linked: manhood, masculine status and success, work, responsibility, domesticity, selfdiscipline, continence. Brian's laddism, far from being a hegemonic masculinity, would appear to be a form of countercultural resistance to the "masculine role".

This last point leads us to the second common thread, which is that this prospect of settling down inspired almost universal dismay and even dread within my sample. Of the 27 interviewees with jobs, only 7 claimed to enjoy their work, and it should be noted that 5 of these had managerial responsibilities. Of those who were unemployed or studying, not one regarded the prospect of work or a career with enthusiasm, although the degree of antipathy varied greatly. Chris, a 22-year old student from a medium-sized town, expresses the mildest antipathy:

N.G. How do you see yourself in five years' time?

C. Erm... Five years' time... probably in a well-paid but quite boring job I expect.

Erm...

N.G. You don't mind that? A boring job?

C. No, just as long as it's, sort of, just nine to five, Monday to Friday. I can spend the evenings and weekends... I see myself with my girlfriend still. I expect we'll probably get married and get a house. ${ }^{71}$

It should be noted that there seems to be an association between the job and settling down with his girlfriend. On the other side there is Ben who threw in his good programming job and his girlfriend, went travelling and was unemployed and single at the time of the interview:

I don't know, I was kind of sick of spending 8 hours a day just tapping on a keyboard or doing something really, really dull [...]. I didn't feel at all satisfied with what I was doing. It was kind of depressing. I'd just come home feeling really bowed down and the days would just go by and go by and go by with the same nothing..$^{72}$

21 Apart from the seven already mentioned, who said they enjoyed their jobs, and two who did not question the need to work hard in life (both from traditional working-class country families), the rest of the sample, $85 \%$, can be situated between these two positions. This perhaps is hardly surprising. Sigmund Freud argues that the pleasure principle in the human psyche leads to a "natural aversion to work" 73 and Karl Marx argues that work under capitalism is "alienating". ${ }^{74}$ However, this leads to a disconcerting syllogism; if being a man means exercising responsibility through work and if work is alienating, then being a man is alienating. In this light, it is significant that 23 of my sample of 60 did not qualify themselves as men, usually because they did not consider themselves responsible, usually because they were going out drinking and clubbing too much and had not 'settled down'. Avoiding the status of manhood creates a space in which pleasure and self-indulgence is allowed. At the same time, it was clear that work is not only a functional imperative, but is also connected to self-esteem. Ben, the ex-programmer, questioned materialist values but was at pains to emphasize that he was not "lazy" or a "scrounger".

Complex issues coalesce and overlap around the subject of work, emerging in the discourse of the interviewees in very different ways and at different levels of consciousness, and often leading to self-contradictory statements. The most common 'solution' to the 'problem' of work was to combine work and pleasure. 18 interviewees were trying or had tried to make money from what they enjoyed, usually music or 
making films, usually with disappointing results. Each knew that if they failed they would have to get a "proper job", which represented failure. The most poignant example was a young agricultural labourer, living with his father on the edge of a picturesque village, who thought he could be a rap star and every day went into an old caravan in his garden to practice. His father said he was being unrealistic.

A small minority, 6 out of 60 , railed against the system and had developed coherent, although often anguished, personal philosophies, like Ben, who had started to question materialist goals, or Jonathan, who had a job assembling furniture in a North London depot and was a biker in his free time:

J. Life isn't exciting and people need to find something that they like doing and that's exciting and is not mundane. I mean working every day and life in general is very mundane.

N.G. Mundane?

J. It's grim.

N.G. Why is it grim?

J. Because you're locked into a system, you need to be working the system to keep away from it, you need to enjoy yourself, you need to work as hard as possible within the system and then you need the get-out which is escapism. Escapism is great for me. ${ }^{75}$

Jonathan and three other interviewees sought adrenalin rushes - bungy-jumping, snow-boarding, downhill speed skiing and, for Jonathan, taking bends at speed - to offset the tedium of their work lives. Perhaps also to be included in this category were two who worked hard during the week and spent the entire weekend in London clubs such as The Ministry of Sound, taking drugs such as ecstasy, dancing and looking for sexual partners. Alternatively, three interviewees had 5-year or 10-year plans. They would work hard now and earn the money to live fully later, like Chota, of BritishIndian origin, on his way to becoming a trader in the City:

I want everything I'm filtering out now to come out in ten years. I want the result and the dividends in ten years. I'm not a very short-term person, I always think ten years' ahead. I have done since the last couple of years anyway. I always ask myself, if I don't make it, is there any point living past thirty. ${ }^{76}$

Four, of whom three from the estates of South East London, were drawn to crime, mostly drugs. Here's one mulling it over:

I've thought about it but I can't make up my mind. It's really difficult. [...] I don't want to get a job where I'm 'oh, I hate this'... cos I feel that's terrible [...]. I hate work. I want something that I love going to do, something I enjoy doing... and at the same time earning my money. [...] I don't want to take the wrong sort of path. There's so many different ways to earn money. I know inside out ways to make money. Stuff like that. But... I prefer to do it legally. [...] Doing it illegally there's always a chance you'll get caught, there's always the risk. [...] I don't want to have no stress, basically, I want a lot of money and no stress. And just be relaxed and free. Worry about no-one, nothing, I've got no problems. It's just paradise. ${ }^{77}$

Such conscious, albeit naïve, calculation is rare, however. From most of the others, both the problem and the solution were much less defined. of the 23 that did not define themselves as men, 19 thought they would have to "grow up", apparently under the impression that once they had grown up everything would be clear, and they would "want" to settle down with a good job and a family. In the meantime, they sought the means to postpone that day, usually by invoking their need to travel. Compare the following three students, who don't know each other, each nearing the end of his studies: 
N.G. You're looking forward to having a career?

Michael Yeah, I do want to do it, yeah I do, but I just don't want to do it at the moment. [...] I want to go for a year, like, go to Asia, work in Australia for 6 months or whatever, or New Zealand and then go to South America and Canada. [...] I've just got it in my head that that's what I want to do. [...] I just can't get on with doing anything else until I've done that. [...] I don't know how it will affect me, going away. I'd like to get a job which allows me to go travelling. I always think I don't want to work in England, but it's not as if I want to leave it altogether. But I just really don't want to work too hard. ${ }^{78}$

Don: I'm going to grow up a bit I think. I'm going to have to. Do the travelling. And then when I come back I'm going to have nowhere to stay, no job, nothing. I'm going to have to sort myself out. From then on I'm going to have... that's the point when I'll start to think about what I'm really going to do. Forcing myself to do something. [...] I think when I come back, I think I will have changed, and I don't know, I could be a completely different ... not a completely different person, but have different goals.

N.G. Travelling for you is more than just travelling?

Don: Yeah. I think after I've done that... travelling is sort of the thing I want to do before I actually completely grow up. ${ }^{79}$

Harry: I definitely want to get married, but not for a long, long time. I don't want to settle down until I'm at least thirty, you know. I haven't got, you know, I've not got plans to get a "proper" job for a while yet. I want to do some more travelling, see the world. ${ }^{80}$

Travel, however, like the other strategies, is a temporary solution. The pressure to conform involves not only ideological issues of self-esteem and social acceptance, but also, by extension, purely practical considerations of survival; as such it is almost impossible to resist. Here is Phil in his thirties, a great clubber and hedonist, preparing to change his ways:

P. The good times have to come to an end.

N.G. Why?

P. Because nothing lasts forever.

N.G. But you'd still like to be having those good times?

P. I'd like to be having the good times, but the effects of the good times I wouldn't want. ${ }^{81}$

Although he didn't say what the effects were, I was reminded of Hogarth's rake, who, at the end of his adventures, finds himself rejected and despised by his community, as well as depleted and impoverished by his own excesses.

There was a similar masculine ambiguity about getting involved in a 'serious' or 'longterm' relationship. Of the 26 in a relationship at the time of the interview, only 6 spoke of love or enriching companionship. The attitudes were complex and layered. Of the 54 heterosexual interviewees prepared to talk about their relationships, almost all considered that having a 'serious' girlfriend was normal and a sign of being a man, just as a 'proper' job was, and something they would all in principle aspire to. Apart from being an approved manner of obtaining access to sexual activity, it conferred selfesteem and social recognition and security. 3 interviewees who had not yet had a 'proper' relationship, and 2 who were in their thirties and did not have a 'proper' girlfriend were embarrassed about the fact; and 3 with little sexual experience were proud of having had one. I felt, too, that those interviewees with issues of selfconfidence, or whose lives were in some way disordered (family break-up, prison, financial difficulties) enjoyed the security and support of a regular girlfriend. On the other hand, a 'serious' girlfriend was also associated with responsibilities and was 
considered to be an important step in the process of 'settling down', which a majority of the interviewees seemed to be trying to push off in one way or another. Perhaps unsurprisingly then, the majority of interviewees tended to contradict themselves when talking on the subject. Here is 27-year-old George from London worrying about a relationship that has lasted on and off for two years and which he had now decided to commit to:

And to be with a girlfriend in the long term, we'll probably have to marry. Which is fine, but which does carry the idea of ... [pause]... boredom..$^{82}$

Or 22-year old Michael from a small town, who has been going out with his girlfriend for a few months:

M. Girlfriends. Like you always think you want one, but when you've got one you think I could do with being by myself for a little while. Yeah, I'm happy I've got a girlfriend.

N.G. So what's the problem?

M. Nothing really, it's just, like, someone else to worry about, someone else you've got to keep happy. ${ }^{83}$

Or alternatively, here is 21-year-old, middle-class Harry from a medium town who did not have a girlfriend at the time, who actually lowered his voice and glanced around furtively as he spoke these words, as if afraid that someone might overhear, although we were completely alone:

Sometimes it's nice just to... personally at the moment I don't want to get a girlfriend at all. All of my mates have... Actually my best mate hasn't got a girlfriend, I don't know if that's just a coincidence. [Lowers voice.] I don't actually want one, do you know what I mean? I'm quite happy just having a good time and meeting people and... having a laugh with people. And just getting along as it were. I just think it's nice to er... sort of... not have to worry about the consequences. Not have to think 'oh gawd I haven't phoned her for a while'. ${ }^{84}$

It should be noted firstly that these feelings were so private that he had not discussed them with his "best mate" and secondly that I heard indirectly that, despite his misgivings, he was going out with a steady girlfriend the following year.

What is most striking in these comments is the lack of emotional commitment or even response to sexual relationships, which emerged in various manners. 3 had an aggressively macho 'love em and leave em' approach to sexual relations, which seems also to be the recommended attitude of $F H M^{85} .6$ others talked, somewhat legalistically, about having a girlfriend who was not actually a 'proper' girlfriend, with whom they slept more or less when it suited them but without any formal responsibility or obligation (although each of them recognised when questioned that this arrangement did not suit their 'unofficial' partner). 8 talked of their "fear of commitment" which was generally felt to be a "bloke thing". 5 believed in love but for some reason had not experienced it. 4 had declared love but not actually felt it. 12 were worried about their lack of emotion and felt there might be something wrong with them (and a few were clearly taking advantage of the anonymous interview to talk about the "problem").

My point is here that if social discourse is a masculine discourse, and if men enjoy a structural advantage, why would we find within this admittedly small but representative sample of British men such reticence towards society and its expectations? If being a man brought benefits in terms of enjoyment, self-expression and prestige, why do the great majority of interviewees not seem to feel them? Why is there so often a feeling of dispirited resignation when talking of life within social 
structures and a wild elation, however transitory, at any departure from those structures? There might be indications that social discourse and structures in Britain are not or are no longer especially 'masculine'. For example, the popular and academic discourse which presents masculine emotion as 'autistic' might be seen as a fundamental shift of social discourse; in the past, emotional reserve or reticence was considered to be a sign of masculine strength and the expression of powerful emotions was associated with 'female' hysteria. Could this be taken as a sign that the masculine linguistic hegemony, which feminist writers such as Françoise Héritier and Mary Daly ${ }^{86}$ considered so universal, has been lost? We can also point to the emergence of countercultural movements in Britain since the 1960s, such as Mods, Skinheads and Punks. As Fiona MacDonald points out in The Graffiti Subculture, ${ }^{87}$ these movements have traditionally been interpreted in the light of Marxist analysis as forms of social protest, which ignores the fact that they are also predominantly masculine movements. In "Girls and Subculture", the British sociologists Angela McRobbie and Jenny Garber argue that women do not create their own subcultures..$^{88}$ If this is the case, could this be an indication that it is above all men who are unhappy with social structures? And, once again, could this be an indication that social discourse is not necessarily 'masculine' or constructed in the interest of men?

What is more, a general impression gained from the young men of my sample is that the main spokespersons for the discourse of settling down and growing up and being a man are not other men, but ironically the women in their lives, usually mothers or girlfriends, who often appear in their discourse as a "a personified superego", to borrow the television critic Brandon Robshaw's phrase. Of the 12 interviewees who discussed their ambitions in life, in 7 spontaneously mentioned the mother as a guiding and inspirational force. It would also seem that mothers and girlfriends seek to correct behaviour that they disapprove of. They reprimand and militate against tasteless jokes ( 5 cases), insensitive and selfish behaviour (17 cases), childishness (8 cases), time- and money-wasting games and activities (13 cases), they urge their boyfriends to get 'proper' jobs ( 7 cases), to go out less with their male friends (9 cases), and generally to "grow up" and accept their responsibilities. 21 interviewees expressed the view that a girlfriend in particular or girlfriends in general wished to change them or their behaviour. Some, usually talking about a current girlfriend, were appreciative of this role:

She keeps me on the straight line..$^{89}$

Or ruefully accepting:

She actually... she knows me a lot more than I actually know myself. I know that. She can read me like a book sometimes. And she knows when I'm lying, I'll tell you that. ${ }^{90}$

Or understanding at least:

I think she has an ideal vision of what a couple should be and she wants to direct us as close to that as possible, I think..$^{91}$

Most were, to varying degrees, resentful or baffled:

The things that my Mum and girlfriend moan about, they're things which just can't be helped. I think that moaning about little things is pointless, because life's too short to be miserable. ${ }^{92}$

It should be noted that whereas the mother most usually played an important and active role in the interviewee's life, communication between father and son was most 
often seen as not as good as with the mother, or else poor. In 19 cases he had left home at some time during the interviewee's upbringing, most frequently unlamented. of those that had lived in a traditional family unit, only 7 got on better with their father than with their mother, and in 4 of these cases it was not because they communicated verbally a lot, but because they shared a 'masculine' hobby or activity, such DIY or cycling. It is also worth noting that, even when the father fulfilled the traditional masculine role as main breadwinner, which was almost always the case when both parents lived together, the mother was usually seen as the dominant presence in the family, who had the final word on family matters ( 21 cases). 6 fathers who were considered to be dominant were also considered to be bullies, tending towards violence. Only 2 fathers were seen as being powerful, loving and communicative figures in the interviewee's life. Generally speaking fathers did not represent for the interviewees an encouraging or enviable role model.

What emerges from these interviews is a strong impression that the masculine role, based on work and family responsibilities, which second wave feminists such as Gloria Steinem considered an essential component of masculine domination ${ }^{93}$, is not an enticing prospect for men but is nevertheless considered to be unavoidable. It seems that, as a result, various delaying tactics, often characterised as 'laddish', are deployed, whether consciously or unconsciously, involving a subversion of patriarchal representations and values, a refusal to engage in work, to engage emotionally in sexual relationships, a refusal of the status of manhood, a refusal to engage in society or accept responsibilities. In this light we can better understand the desire to debunk or unmask ideal masculine values, which is so evident in FHM. More generally, it can be argued that politically incorrect humour is used subversively to undermine dominant social values.

41 At the heart of laddism is the creation of masculine space, where men can 'be themselves'. This most famously takes the form of the 'lads' night out', whether a stag party in Dublin or an ordinary Friday evening in the local pubs and clubs. To understand just how formulaic these evenings are supposed to be, it is sufficient to compare the following two passages, the first from FHM, the 'lad mag' par excellence, the other taken two years later from an article about laddism in a regional newspaper:

In order to amuse himself on a night-out, the fun-loving gentleman will embark upon a course of heavy alcohol consumption, accompanied by a few cheeky phrases levelled at a bored barmaid and a fight involving pork scratchings and kebab meat.

A typical evening for a rugby player is supposed to consist of 14 pints of lager, a round of sexist songs, a fistfight and a greasy kebab. ${ }^{95}$

Heavy alcohol consumption breaks down conditioned constraints. In both cases it is implied that there are no women present, apart from the "bored barmaid" and masculine behaviour is anti-social, involving sexism and fighting. Another key element is the male group. For the interviewees of my sample, membership of a masculine band of friends had great importance. It was my impression, admittedly subjective, that the 18 who were part of such a group were the happiest of my sample and those that had no masculine friends were the unhappiest. In the words of one of my interviewees, the group of male friends was "magical and reassuring". ${ }^{96}$ Typically, they had become friends at school, where they formed a powerful clique and neglected work in favour of "having a laugh". After school they still meet regularly, usually at weekends to go out drinking together. The participation of girlfriends, although tolerated, is disapproved 
of (and can lead to bad feeling within the group), as in their presence the men cannot "be themselves". All communication within the group tends to take the form of "merciless piss-taking" the group, making politically incorrect and frequently sexist jokes and sometimes forcefully debating political issues which may range from Britain's place in Europe to the local controversy of a road being built through a protected wetland. They do not share their feelings or discuss personal problems. It seemed to me that part of the success of FHM and Loaded is that they imitated the dynamic of such a masculine group. However, the masculine bonded group, too, seems to be also a temporary solution, as 33-year old Jim suggests:

We talk about our relationships not in the way I would discuss it with my girlfriend. Fair bit of ribbing going on about who's most under the thumb or settled down, those sorts of things. [...] I think we're all getting to an age where it's pretty inevitable that we'll be settling down, having kids and maybe getting married. I think there's a bit of like 'you go first', 'no you go first', seeing who's ready to start that off. Whether it's like a collective anxiety thing, I don't know. ${ }^{98}$

Jim is the main breadwinner in the couple, but did not at all give the impression of being the dominant partner. On the contrary, it seems as if he is acceding reluctantly to his girlfriend's discourse and grumbling about it secretly to his friends. It is perhaps significant and related that Jim enjoys video games, but because his girlfriend finds the activity childish, he waits until she leaves the flat before playing. It seemed to me as if not only the home but the relationship itself might be interpreted as a feminine space.

This analysis of the interviews challenges the traditional feminist assumptions that patriarchy and patriarchal masculinities are necessarily maintained by men in the interest of men. The dominant discourse may be about men and about masculine success, without being a masculine discourse. On the contrary, it may even be argued that masculinities are actively shaped by women according to a feminine ideology of the home. This is not necessarily a new observation in Britain. For Andrew Tolson, the pioneer of masculinity studies in Britain, the mother is "the principle representative of the middle class family." ${ }^{99}$ According to Michael Young and Peter Willmott in Family and Kinship in East London, in the Bethnal Green area of East London in the 1950s "the mother is the head and centre of the extended family." 100 Nor is this phenomenon restricted to Britain. The feminist writer, Barbara Ehrenreich in The Hearts of Men, argues that American men since the 50s frequently experience the process of settling down as a surrender of volition to a feminine world. ${ }^{101}$

We can trace this analysis further back in time. As the literary critic Frank Kermode points out, D.H. Lawrence believed that women were the real "social agents" and that the miners of his generation had been "got under and made good" by their wives. ${ }^{102}$ In a speech delivered in 1955, later published as an essay under the title "The Condition of Women in Primitive Societies and in Our Own", the British anthropologist E.E. Evans Pritchard expresses his belief that English men have lost a great part of the authority that they used to enjoy as head of the family and have adopted a passive and defensive attitude within the home. ${ }^{103}$ The theme can be traced further back in time. F.M.L. (Michael) Thompson, the British social historian of the $19^{\text {th }}$ century, suggests that "the father wielded the strap but most of the rules emanated from mother" 104 and that feminine control of marriage arrangements led to feminine definitions of acceptable masculinity: 
It is clear that the effective determination of marrying standards, and their enforcement, were substantially women's business, with authority and influence being exercised by wives, mothers and grandmothers [...]. It was women who composed the invitation lists for social events and thus decided which young men came within the pale of the socially acceptable. And it was womenfolk who developed the appropriate classificatory vocabulary about where to draw the line, chiefly for application to young men. ${ }^{105}$ Victorian men, "domesticity [...] meant submitting to a feminized ambience". ${ }^{106}$ Tosh argues that this masculine perception led to the creation of homosocial spaces that allowed men to escape the influence of women, not just masculine clubs and rooms reserved for men in domestic architecture (the gun-room, the smoking room etc.), but also, more generally, colonial adventure, ${ }^{107}$ in which analysis the former British empire must be considered the ultimate masculine space. Generally he notes the rise of homosociality and so-called "Uranian" friendships between men. ${ }^{108}$ The theme can be traced back further. Historians of the Early Modern period, such as Laura Gowing, Patricia Crawford and Jacqueline Eales have explored how women of this period used patriarchal institutions such as the Calvinist sects, the Church generally and the Ecclesiastical courts to militate against masculine drunkenness, infidelity, physical abuse and laziness and generally to ensure that men lived up to their patriarchal pretensions. Laura Gowing suggests that women acquired at this time "a verbal and legal authority that was at once powerful and fragile" 109 and Jacqueline Eales speaks of the feminine role as "moral arbiter of acceptable social behaviour". ${ }^{110}$ The historian Anthony Fletcher, speaking of the onset of patriarchal Calvinist masculinity in the early $17^{\text {th }}$ century, emphasises its drawbacks for men:

manhood in itself was more questionable, it is suggested, than we have realised: more problematic to achieve, more problematic to retain and exercise according to the rules that society laid down. For the core of early modern patriarchy was household order and much was expected of men in that regard. ${ }^{111}$

whis would perhaps suggest that Calvinist patriarchy, while ostensibly reinforcing masculine domination, in fact came at a price, by expecting men to live up to their patriarchal pretensions and therefore, so to speak, to earn their status. It may be added that, according to Jacqueline Eales, it was agreed amongst Calvinist theologians and theoreticians that women should obey their husbands "unless their commands conflicted with those of God". ${ }^{112}$ If this is the case, women would have had considerable influence as arbitrators of masculinity.

This analysis encourages us to think of patriarchy not as a solid and monolithic structure imposed by men, but as a precarious, shifting interaction between gender ideologies that have emerged around the work and responsibilities involved in reproduction. Although men have most usually obtained the advantage in any contest over the division of labour in child-care (as women are literally left holding the baby) and sought to naturalise the advantage through masculinist ideologies, this would not preclude the emergence of feminine ideologies and practices that seek to minimise the feminine disadvantage and masculine abuse of power. We can imagine that direct confrontation would not produce the best results and therefore envisage the evolution of subversive strategies which seek to influence masculine conditioning or even define masculinities according to perceived feminine interests. In this scenario, the prestige women accorded to a man would be conditional on his behaviour. Such feminine 
participation in the construction of masculinities is not unusual or limited to the English-speaking world. In the collection of ethnographical gender studies entitled Dislocating Masculinity, ${ }^{113}$ a number of contributors note this practice. For example, Chenjerai Shire, speaking of the Shona in his native Zimbabwe, says that "women constructed masculinities right through the lives of men, from birth to adulthood."114 Lin Foxhall challenges Michel Foucault's analysis of masculine domination in Periclean Athens and suggests that women, by marrying young, spanned the generations of men and provided cultural continuity, which constrained masculine freedom of action. ${ }^{115} \mathrm{In}$ "The Paradoxes of Masculinity", Deniz Kandiyoti perceives among young Turkish men a reaction against patriarchal masculine identities which are inculcated or encouraged by the women of their families. ${ }^{116}$

50 We can therefore imagine that through this subversive or recuperative process the advantages accruing to men in patriarchy may be whittled away until they are not experienced as advantages at all but as constraints. This masculine perception would not necessarily take place on a conscious level, but would perhaps most likely emerge in self-contradictory discourse, as we have seen in the interviews of my own sample, and would be filtered through issues of self-esteem, perceptions of right and wrong, calculations of self-interest and the sublimation of desires. If hegemonic masculine discourse has really been subverted by a feminine ideology, we can also imagine the emergence of equally unconscious masculine counter-strategies or counter-practices, emerging through fashion and humour, which seek to undermine hegemonic patriarchal ideals and set up alternative 'authentic' models of masculinity which allow for greater freedom. This scenario might shed light generally on the meaning of postwar countercultural movements in Britain but particularly on the emergence of new laddism in the 1990s, with its emphasis on masculine pleasure-seeking, its impatience with social constraints, its ridicule of masculine pretensions, its self-lacerating representation of the weak man and more generally its use of subversive humour. Ironically, this interpretation would ostensibly have lads and feminists fighting for the same cause. However, as Barbara Ehrenreich suggests in "The Decline of Patriarchy", ${ }^{117}$ the dismantling of patriarchy might lead to new and worse forms of masculine abuse. It would be provocative and sensationalist to suggest that patriarchy is a feminine construction, but it might be considered, from a feminine point of view, as an ideological means, faute de mieux and in the absence of reproductive instincts, of containing masculine abuse and obtaining masculine contribution, however unequal, to the work that reproduction entails.

\section{BIBLIOGRAPHY}

Websites (accessed in 2007):

Audit Bureau of Circulations (ABC). http://www.abc.org.uk

Office of National Statistics (ONS). 2001 Census. http://www.statistics.gov.uk/census/ 
Magforum (Magazine and Magazine Publishers). http://www.magforum.com

Television shows:

Dad's Army. BBC. 8 series and 12 "specials". 1968-1977. Screenwriters, Jimmy Perry and David Croft. Producer, David Croft.

Eastenders. BBC. 1985 ongoing. Executive Producer, John Yorke.

Men Behaving Badly. Hartwood Films. 44 episodes. ITV, 1992-1995. BBC, 1995-2002. Creator and screenwriter, Simon Nye.

Micawber. ITV. 4 episodes. December 2001. Creator, John Sullivan. Executive Producer, David Reynolds.

Only Fools and Horses. BBC. 52 episodes in 8 series (+ 14 "specials"). 1981-1996. Screenwriter: John Sullivan. Producers, Ray Butt, Gareth Gwenlan, Louis Heaton.

Some Mothers Do ‘Ave ‘Em. BBC. 22 episodes. 1973-1975, 1978. Screenwriter, Raymond Allen and Michael Crawford. Director, Sydney Lotterby. Producer, Michael Hills.

Whatever Happened to the Likely Lads? BBC. 1973-1974. 26 episodes in 2 series. Producers, Bernard Thompson and James Gilbert.

Books and articles:

Adams, Tim. "Why is this the biggest selling men's weekly? It must be ... NUTS. The Observer Review. 23 May, 2005, 1-2.

Arlidge, John. “Men Fight Back over Sexist TV Adverts". The Observer. 16 January 16 2002, 4. Baron-Cohen, Simon. The Essential Difference. London and New York: Penguin. 2004.

Benwell, Bethan ed. Masculinity and Men's Lifestyle Magazines. Oxford: Blackwell, 2003.

Beynon, John. Masculinities and Culture. Buckingham and Philadelphia: Open University Press, 2001.

Bourdieu, Pierre. La Domination masculine. Paris: Seuil. 1998.

Brittan, Arthur. Masculinity and Power. Oxford and New York: Blackwell, 1989.

Chapman, Rowena. "The Great Pretender: Variations on the New Man Theme” in Male Order: Unwrapping Masculinity, edited by Rowena Chapman and Jonathan Rutherford. London: Lawrence and Wishart, 1988.

Connell, R.W. Gender and Power. Stanford: Stanford University Press. 1987.

Cornwall, Andrea and Nancy Lindisfarne eds. Dislocating Masculinity. London: Routledge, 1994.

Crawford, Patricia. Women and Religion in England, 1500-1720. London: Routledge, 1993.

Crewe, Ben. Representing Men: Cultural Production and Producers in the Men's Magazine Market. Oxford and New York: Berg, 2003.

Dawkins, Richard. The Selfish Gene. Oxford and New York: Oxford University Press. 1976.

Dworkin, Andrea. Pornography: Men Possessing Women. London: The Women's Press Limited, 1981.

Eales, Jacqueline. Women in Early Modern England, 1500-1700. London: UCL Press, 1998.

Ehrenreich, Barbara. The Hearts of Men: American Dreams and the Flight from Commitment. New York: Anchor Books/Doubleday, 1983. 
--. "The Decline of Patriarchy" in Constructing Masculinity, edited by Maurice Berger, Brian Wallis and Simon Watson. New York and London: Routledge, 1995.

Fletcher, Anthony. Gender, Sex and Subordination in England 1500-1800. 1999; Yale: Yale University Press, 1995.

Foxhall, Lin. "Pandora Unbound: a feminist critique of Foucault's History of Sexuality". In Dislocating Masculinity, edited by Andrea Cornwall and Nancy Lindisfarne. London: Routledge, 1994.

Freud, Sigmund. Le Malaise dans la culture (1948). Translated by Pierre Cotet, René Lainé and Johanna Stut-Cadiot. Paris: Quadrige/Presses Universitaires de France, 1995.

Gowing, Laura. “Language, Power and the Law: Women's Slander Litigation in Early Modern London". In Women, Crime and the Courts in Early Modern England, edited by J. Kermode and G. Walker. London: UCL Press, 1994.

Growse, Nicholas. "Le Phénomène du New Lad dans les magazines spécialisés pour hommes: L'état de la masculinité en Grande-Bretagne." PhD. Diss. Université de Paris 7., 2008.

Jackson, Caroline. Lads and Ladettes: Gender and a Fear of Failure. Maidenhead and New York: OUP, 2006.

Jackson, Peter, Nick Stevenson and Kate Brooks. Making Sense of Men's Magazines. Cambridge: Polity, 2001.

Jones, Steven. Y: The Descent of Men. London: Abacus, 2002.

Jung, C.G. "The Relations between the Ego and the Unconscious" (1928). In Jung: Selected Writings, edited by Anthony Storr. London: Fontana, 1998.

Kandiyoti, Deniz. “The Paradoxes of Masculinity”. In Dislocating Masculinity, edited by Andrea Cornwall and Nancy Lindisfarne. London: Routledge, 1994.

Kermode, Frank. Lawrence. London: Fontana, 1973.

MacDonald, Nancy. The Graffiti Subculture: Youth, Masculinity and Identity in London and New York. Basingstoke and New York: Palgrave MacMillan, 2002.

Marx, Karl. “L'Idéologie allemande” (1845). In Marx: études philosophiques. Paris: Editions Sociales, 1977.

McRobbie, Angela and Jenny Garber. "Girls and Subcultures” (1975). In The Subcultures Reader, edited by Ken Gelder and Sarah Thornton. London: Routledge, 1997.

Mort, Frank. Cultures of Consumption - Masculinities and Social Space in Late Twentieth Century Britain. London: Routledge, 1996.

Nathanson, P. and K. Young. Speading Misandry: The Teaching of Contempt for Men in Popular Culture. New York: McGill Queen's UP, 2002.

O’Hagan, Andrew. “The Lad Stripped Bare”. The Guardian. June 16, 2004, G2, 1-4.

Robson, Brandon. "How to be Good. Has Ladlit Reached its Closing Time?" The Independent Magazine. August 24, 2002, 18.

Shire, Chenjerai. "Men Don't Go to the Moon". In Dislocating Masculinity, edited by Andrea Cornwall and Nancy Lindisfarne. London: Routledge, 1994.

Southwell, Tim. Getting Away with It: The Inside Story of Loaded. London: Ebury, 1998. 
Steinem, Gloria. “The Masculine Mystique”. In Men and Masculinity, edited by Joseph Pleck and Jack Sawyer. New Jersey: Spectrum, 1974.

Summers, Sue. "Has TV had a makeover?" The Observer, 12 March 2003, Review Section, 12.

Taylor, Gary. "You Vile, Hopeless, Incompetent Brits", The Guardian, December 10 2003, G2, 10.

Thompson, F.M.L. The Rise of Respectable Society: A Social History of Victorian Britain, 1830-1900.

London: Fontana Press, 1988.

Tolson, Andrew. The Limits of Masculinity. London: Tavistock Press, 1977.

Tosh, John. Manliness and Masculinities in Nineteenth Century Britain. London and New York: Pearson Education Ltd, 2005.

Tosh, John. A Man's Place: Masculinity and the Middle Class Home in Victorian Britain. Harlow, London and New York: Pearson Longman, 1999.

Willis, Paul. Learning To Labour: How Working Class Kids Get Working Class Jobs. Brookfield and Aldershot: Ashgate Publishing Limited, 1993, 1977.

Young, Michael and Peter Willmott. Family and Kinship in East London. Harmondsworth: Penguin, $1967,1957$.

\section{NOTES}

1. John Beynon, Masculinities and Culture (Buckingham and Philadelphia: Open University Press, 2001), 94.

2. Dad's Army, BBC, 8 series and 12 "specials", 1968-1977. Script writers: Jimmy Perry and David Croft. Producer: David Croft.

3. Some Mothers Do Ave Em, BBC, 22 episodes, 1973-1975, 1978. Scriptwriters: Raymond Allen and Michael Crawford. Director: Sydney Lotterby. Producer: Michael Hills.

4. Whatever Happened to the Likely Lads? BBC, 26 episodes in 2 series, 1973,1974. Scriptwriters: Dick Clement and Ian Lefrenais. Producers: Bernard Thompson and James Gilbert.

5. Fawlty Towers, BBC, 12 episodes in 2 series, 1975, 1979. Scriptwriters: John Cleese and Connie Booth. $1^{\text {st }}$ series producer: John Howard Davies. $2^{\text {nd }}$ series producer: Douglas Argent.

6. Only Fools and Horses, BBC. 52 episodes in 8 series and 14 "specials", 1981-1996. Writer and editor: John Sullivan. Producers: Ray Butt, Gareth Gwenlan, Louis Heaton.

7. Men Behaving Badly, Hartwoods Films. 1992-1994 on ITV, 1995 on BBC1. In 1995 the show won the "Most Popular Comedy Series" television award.

8. Micawber. ITV. 4 episodes. December 2001. Creator: John Sullivan. Executive Producer: David Reynolds.

9. John Arlidge, "Men Fight Back over Sexist TV Adverts", The Observer, January 16, 2002, 4. These advertisements usually show men as slow-witted compared to the female target.

10. Sue Summers, "Has TV had a Makeover?", The Observer Review, March 2, 2003, 12.

11. Nick Hornby, author of Fever Pitch (1993) and High Fidelity (1995).

12. Tony Parsons, author of many novels such as One For My Baby (2001), Man and Wife (2003) and The Family Way (2004).

13. Brandon Robshaw, "How to be Good. Has Ladlit Reached its Closing Time?" The Independent Magazine, August 24, 2002, 18.

14. Gary Taylor, "You Vile, Hopeless, Incompetent Brits", The Guardian, December 12, 2003, G2, 10. 15. Unlike sociologists, Neo-Darwinians consider that human behavioural characteristics are fundamentally governed by the same opportunistic evolutionary principles as govern those of 
other animals. Their major tool of analysis is Game Theory, which studies the outcome of competitive interaction. The Harvard zoologist E.O. Wilson founded a new hybrid discipline in the 1970s, which he called "Sociobiology", the object of which was to integrate the study of human society with the wider study of animal behaviour. Since the 1990s, the controversial term "Sociobiology" has been abandoned in favour of "Evolutionary Psychology", best represented by such writers as Steven Pinker, author of The Language Instinct (London: Penguin, 1995).

16. The Observer. "So it's a woman's world", The Observer, 15 August, 2004, 3.

17. The study was carried out in 2009 with 238 children at two primary schools in Kent. According to the University website, "Bonny Hartley, of the University of Kent, who presented the research, said: 'By seven or eight years old, children of both genders believe that boys are less focused, able, and successful than girls - and think that adults endorse this stereotype."

University of Kent, http://www.kent.ac.uk/news/stories/girls-believe/2010, accessed 2010.

18. R. Connell, Gender and Power (Stanford: Stanford University Press, 1987), 31.

19. Arthur Brittan, Masculinity and Power (Oxford: Blackwell, 1989), 131.

20. Brittan, Masculinity and Power, 5.

21. "La force de l'ordre masculin se voit au fait qu'il se passe de justification : la vision androcentrique s'impose comme neutre et n'a pas besoin de s'énoncer dans des discours visant à la légitimité." Pierre Bourdieu, La Domination masculine (Paris: Seuil, 1998), 15.

22. Françoise Héritier, Masculin/féminin: la pensée de la différence (Paris: Odile Jacob, 1996), 19-22, 72-86, 143.

23. The three pillars as conceived by Claude Lévi-Strauss in Les Structures élémentaires de la parenté (1949) are the prohibition of incest, the division of labour between the sexes, and the existence of some socially recognised form of sexual union.

24. Oh why did God

Creator wise, that peopled highest heaven

with spirits masculine, create at last

This novelty of earth, this fair defect

of nature.

John Milton, Paradise Lost, Book X, L. 888.

25. The mytho-poetic movement, founded by Robert Bly, is a men's movement inspired by the thinking of the psychologist Karl Jung. It holds, in particular, that men need to be ritualistically initiated into manhood, and that masculinity can take any of several 'archetypal' forms, as are found and exemplified in traditional folk legends (for example, king, jester, warrior or magician). A number of men's groups sprang up in the USA and the UK over the course of the 1990s, seeking to put their members in touch with their masculinity.

26. Robert Bly, Iron John: A Book about Men (Reading: Massachusetts, Addison-Wesley, 1990), 2.

27. Sam Keen, Fire in the Belly (New York and London: Bantam, 1991), 14.

28. P. Nathanson and K. Young, Spreading Misandry: The Teaching of Contempt for Men in popular Culture (New York: McGill Queen's UP, 2002).

29. Tolson, The Limits of Masculinity (London: Tavistock Publications, 1977), 69.

30. Brittan, Masculinity and Power, 28.

31. Beynon, Masculinities and Culture, 66.

32. Mairtin Mac an Ghaill, The Making of Men: Masculinities, Sexualities and Schooling (Buckingham: OUP, 1994), 179.

33. Steve Jones, Y: The Descent of Men (London: Abacus, 2002), 23.

34. Eric Zemmour, Le Premier sexe (Paris: Denoël, 2006), 72.

35. Andrea Dworkin, Pornography: Men Possessing Women (London: The Women's Press, 1979), 65.

36. As David Hepworth, former editorial director of Emap Metro, explained to me in an interview in 2006, FHM, through a process known as "saming" ("the swift adoption of best practice"), became the template for all subsequent men's magazines, including the popular men's weeklies 
Zoo and Nuts. In other words, although FHM has lost pride of place to the weekly magazines, its spirit lives on. (Nicholas Growse, op. cit., Appendices, 24)

37. Frank Mort, Cultures of Consumption: Masculinities and Social Space in Late Twentieth-Century Britain (London and New York: Routledge, 1996), 15-22.

38. Mort, Cultures of Consumption, 20.

39. The first issue sold 59,400 copies and Loaded broke the 100,000 sales barrier with its ninth issue. Its first audited yearly sales figure was 96,000 and this rose by $82 \%$ to 174,763 for the period Jul-Dec 1995.

Magazine and Magazine Publishers' Website, http://www.magforum.com, "Men's magazines", accessed August 2006.

40. $\mathrm{ABC}$ (Audit Bureau of Circulations), http://www.abc.org.uk.

41. "Editorial," Loaded, May 1998.

42. Paul Willis, Learning to Labour: How Working Class Kids Get Working Class Jobs (Brookfield and Aldershot: Ashgate Publishing Limited, 1977). Willis's thesis is that the working class "lads" of his study in a Midlands school felt that the long-term benefits of hard work and good behaviour did not outweigh the immediate pleasure of avoiding work and doing as one pleased.

43. Tim Southwell, Getting Away with It: The Inside Story of Loaded (London: Ebury, 1998), 61.

44. Carolyn Jackson, Lads and Ladettes in School: Gender and a Fear of Failure (Maidenhead: Open University Press, 2006), 9-11.

45. Peter Jackson, Nick Stevenson and Kate Brooks, Making Sense of Men's Magazines (Cambridge: Polity, 2001).

46. Tim Adams, The Observer Review, May 25, 2005, 1-2.

47. Nicholas Growse, Le Phénomène du New Lad dans les magazines spécialisés pour hommes: l'état de la masculinité en Grande-Bretagne (PhD. Diss. Université de Paris 7, 2008) Appendices 3. The appendices are numbered independently of the main body of the thesis.

48. FHM, October 2000, 98.

49. FHM, November 2000, 154.

50. For example, in a question and answer with Stuart Pierce and Steve Cram 5 questions out of 10 are concerned with morality:

Ever twatted a fan?

Ever taken advantage of a groupie's offer?

Have you ever tripped up a detested rival?

Ever used your name to get yourself out of trouble?

Ever feigned an injury?

FHM, November 2000, "Sin Bin", 349.

51. For example in the "Sin Bin" question and answer column;

"Finally, do you ever jump in the bath with the boys after a big win?" (FHM, October 2000, 343)

"Ever thrown soap at another player's genitals?" (FHM, December 2000, 399)

52. To the singer Corey:

Do you recall the day you realised that naïve strangers would let you fiddle with them?

FHM, November 2000, "Quote Unquote: Corey", 82.

53. For example in an interview with Al Murray the comedian in December 2000, we find the following questions:

What about toilet breaks - you must have a bladder of steel to keep all that liquid in for 2 hours? How long into a relationship does it become ok to fart in front of a lady?

As a public schoolboy, were you as secretive at masturbating as you are now at farting?

FHM, December 2000, “Quote Unquote: Al Murray”, 124.

54. FHM, December 2000, “Quote Unquote: Jose Washbourn”, 70.

55. FHM: Do you want a hug?

Corey: No, I don't want a fuckin' hug! 
FHM, November 2000, 82.

56. FHM, July 2002, 42.

57. FHM, December 2000, 74.

58. The expression "new laddism" is used, especially by sociologists, to distinguish the phenomenon that arose in the 1990s from the earlier notion of young working class masculinity as described by Paul Willis in Learning to Labour.

59. Adams, "Why is this the biggest...," 1-2.

60. Rowena Chapman, "The Great Pretender", in Unwrapping Masculinity, eds Rowena Chapman and Jonathan Rutherford (London, Lawrence and Wishart, 1988).

61. As both the first editor of FHM, Mike Soutar, and his immediate superior, EMAP editorial director David Hepworth made plain to me in separate interviews, FHM was produced at the behest of the advertising agencies, who were looking for a marketing platform that could access young men collectively. The magazine's goal, before its extraordinary success became known, was simply to satisfy the advertisers. Growse, Le Phénomène du New Lad, appendices B1 and B2.

62. The transcripts are published in appendices C and D of Nicholas Growse, op. cit. 10 are complete, the remaining 50 are composed of key extracts. The appendices are numbered independently of the main body of the thesis.

63. Office of National Statistics (ONS), 2001 Census, http://www.statistics.gov.uk/census/

64. I began each interview with the rather strange but fruitful question: "Do you consider yourself to be a man?"

65. Growse, Le Phénomène du New Lad, 403.

66. The Harvard professor of Sociology Talcott Parsons developed the functionalist principles of Role Theory in works such as The Structure of Social Action (1937), Essays in Sociological Theory, Pure and Applied (1942) and The Social System (1951).

67. Mirra Komarovsky, a former student of Talcott Parsons, developed Sex Role Theory in two articles published in the American Sociological Review, "Cultural Contradictions and Sex Roles" (1946) and "Functional Analysis of Sex Roles" (1950).

68. Mirra Komarovsky, "Functional Analysis of Sex Roles", American Sociological Review, August 1950, 511.

69. Gloria Steinem, "The Masculine Mystique", in Men and Masculinity, eds Pleck and Sawyer (Englewood Cliffs, Prentice Hall, 1974), 135.

70. Max Weber, L'Éthique protestante et l'esprit du capitalisme (Paris, Plon, 1967 (1964)) 101.

71. Growse, Le Phénomène du New Lad, 388.

72. Growse, Le Phénomène du New Lad, 329.

73. Sigmund Freud, Le Malaise dans la culture, trans. (Paris: Quadriges/Presses Universitaires de France, 1998) 23.

74. Karl Marx, 'L'Idéologie allemande', in Marx: études philosophiques (Paris: Editions Sociales, 1977).

75. Growse, Le Phénomène du New Lad, 237.

76. Growse, Le Phénomène du New Lad, 243.

77. Growse, Le Phénomène du New Lad, 277.

78. Growse, Le Phénomène du New Lad, 326.

79. Growse, Le Phénomène du New Lad, 335.

80. Growse, Le Phénomène du New Lad, 85.

81. Growse, Le Phénomène du New Lad, 68.

82. Growse, Le Phénomène du New Lad, 281.

83. Growse, Le Phénomène du New Lad, 325.

84. Growse, Le Phénomène du New Lad, 83. 
85. Just look into her eyes when she tells you that she loves you. Now picture the same face, with $20 \mathrm{lbs}$ hanging from the chin, and smothered in wrinkles ... Leave the witch. FHM, November 2001, "Love", 207.

86. Mary Daly, Gyn/Ecology: The Metaethics of Radical Feminism (London: The Women's Press, 1991).

87. Nancy MacDonald, The Graffiti Subculture: Youth, Masculinity and Identity in London and New York (Basingstoke et New York, Palgrave MacMillan, 2002), 45.

88. Angela McRobbie and Jenny Garber, "Girls and Subcultures", in The Subcultures Reader, ed. Ken Gelder and Sarah Thornton, 112-20.

89. Growse, Le Phénomène du New Lad, 217.

90. Growse, Le Phénomène du New Lad, 52.

91. Growse, Le Phénomène du New Lad, 118.

92. Growse, Le Phénomène du New Lad, 448.

93. For example, Gloria Steinem, in an essay entitled "The Myth of Masculine Mystique", argues that the masculine role implies for men "perpetuating their superiority over women", and the feminine role implies for women "suppressing their intellect, accepting their second-class position and restricting all normal ambitions to the domination of their children".

Gloria Steinem, "The Masculine Mystique", in Men and Masculinity, eds Joseph Pleck and Jack Sawyer (New Jersey: Spectrum, 1974), 134.

94. FHM, November 2000, 43.

95. East Anglian Times, August 19, 2002, 32.

96. Growse, Le Phénomène du New Lad, 260.

97. Growse, Le Phénomène du New Lad, 260.

98. Growse, Le Phénomène du New Lad, 288.

99. Tolson, The Limits of Masculinity, 26.

100. Michael Young and Peter Willmott, Family and Kinship in East London (Harmondsworth: Pelican, 1957), 49.

101. Barbara Ehrenreich, The Hearts of Men: American Dreams and the Flight from Commitment (New York and London: Anchor, 1983).

102. Frank Kermode, Lawrence (London: Fontana, 1973), 8.

103. I have paraphrased here from a French translation of the English text.

Edward Evans Pritchard, «La condition de la femme dans les sociétés primitives et dans la nôtre " in La femme dans les sociétés primitives et d'autres essais d'anthropologie sociale, trans. Anne and Claude Rivière (Paris: PUF, 1965) 44.

104. F.M.L. Thompson, The Rise of Respectable Society: A Social History of Victorian Britain, 1830-1900 (London: Fontana Press, 1988), 131.

105. Thompson, The Rise of Respectable Society, 103.

106. John Tosh, Manliness and Masculinities in Nineteenth-Century Britain (Harlow, London and New York: Pearson Longman, 2005), 206.

107. Tosh, Manliness and Masculinities, 200.

108. Tosh, Manliness and Masculinities, 206.

109. Laura Gowing, "Language, Power and the Law: Women's Slander Litigation in Early Modern London", in Women, Crime and the Courts in Early Modern England, ed. J. Kermode and G. Walker (London: UCL Press, 1994), 127.

110. Jacqueline Eales, Women in Early Modern England, 1500-1700 (London: UCL Press, 1998), 107.

111. Anthony Fletcher, Gender, Sex and Subordination (New Haven and London: Yale University Press, 1995), 202.

112. Jacqueline Eales, Women in Early Modern England, 96.

113. Andea Cornwall and Nancy Lindisfarne eds, Dislocating Masculinity (London: Routledge, 1994).

114. Chenjerai Shire, "Men Don't Go to the Moon", in Cornwall and Lindisfarne eds, op. cit., 153.

115. Lin Foxhall, "Pandora Unbound", in Cornwall and Lindisfarne eds, op. cit., 133-46. 
116. Deniz Kandiyoti, "The Paradoxes of Masculinity”, in Cornwall and Lindisfarne eds., op. cit., 198.

117. Barbara Ehrenreich, "The Decline of Patriarchy", in Maurice Berger, Brian Wallis and Simon Watson eds, Constructing Masculinity (New York and London: Routledge, 1995).

\section{ABSTRACTS}

This paper examines the representation of the 'weak man' (or 'useless bloke') in contemporary popular British culture, most visibly in television comedy, but also apparent in men's magazines such as FHM and Loaded, in popular 'confessional' novels of the genre inaugurated by Nick Hornby, and even noted in theatre and popular science writing. While many writers and commentators have attributed this tendency to a rise in feminism and feminine power, this paper suggests that the representation is primarily produced by men for masculine consumption. It argues that it might be symptomatic of a masculine rejection of patriarchal values which are no longer felt by men to be in their interest.

\section{INDEX}

Keywords: lads, laddism, lad mags, Loaded, FHM, British masculinities, weak men, blokes

\section{AUTHOR}

\section{NICK GROWSE}

Nick Growse is English but has lived in France for over 20 years. He spends most of his time travelling between the Dordogne, where he lives with his family, and Paris where he teaches marketing and related business subjects at Ipag. The subject of his doctoral thesis was the rise of popular British men's magazines such as Loaded and FHM in the 1990s and their relation to the popular British masculine culture called 'laddism' or 'new laddism'. Since then he has carried out research on connections between masculine identities and racial identities, the history of modern masculinities in the modern period of British history and the history of gender theory. His publications include "The Ideology of Emotion" (Etudes Lawrenciennes 43, Presses Universitaires de Paris Ouest, Paris, 2012) and "L'empirisme anglo-saxon : approche objective ou idéologique ?" in Mankin Robert (ed.), Travaux en cours, No. 5, December 2009. 